Volume 4 No. 1, Juni 2019

P ISSN 2442-594X | E ISSN 2579-5708

http://journal.iainlangsa.ac.id/index.php/tibyan

DOI: $10.32505 /$ tibyan.v4i1.890

\title{
HERMENEUTIKA SUFISTIK: TELAAH EPISTEMOLOGI TAKWIL IBN ‘ARABI
}

Sufistic Hermeneutics: Study of Epistemology of Ibn 'Arabï's Ta'wìl

\author{
Sansan Ziaul Haq \\ Kelompok Keahlian Ilmu Kemanusiaan FSRD ITB Bandung \\ ziaulhaqsansan25@gmail.com
}

\begin{abstract}
:
The validity of Ibn 'Arabi's ta'wìl is much debated by experts, as is ishāri interpretationin general. Some academics regard it as a deconstructive interpretation which subdues the Qur'anic text to mystical-gnostic teachings. But not a few argue that his mystical interpretation is in harmony with the principle of textuality. This article will discuss the epistemological construction of Ibn 'Arabi' ta'wil through an analysis of the hermeneutical assumptions he introduced. By using hermeneutic and sufistic psychology approaches, this qualitative research concludes that the ta'wil practiced by Ibn 'Arabi is a dialectical process between text and psychic-spiritual context, thus capturing various meanings in the Holy Text as a reflection of multidimensional reality. This kind of interpretation is literal because it imparts textual meaning, andat the same time spiritual because it also reaches inner unveiling.
\end{abstract}

Keywords: Ibn 'Arabì's Ta'wìl, Sufi Hermeneutics, Psychic-spiritual Context

\begin{abstract}
Abstrak
Validitas takwil Ibn 'Arabi banyak diperdebatkan oleh para ahli, seperti halnya tafsir isyari secara umum. Sebagian kalangan akademik mengangapnya sebagai interpretasi dekonstruktif yang menundukkan teks Alquran kepada ajaran mistik-gnostis. Namun tak sedikit yang berpendapat bahwa penafsiran mistiknya selaras dengan prinsip tekstualitas. Artikel ini akan mendiskusikan konstruksi epistemologi takwil Ibn 'Arabīmelaluianalisis terhadap asumsiasumsi hermeneutis yang diperkenalkannya. Dengan menggunakan pendekatan hermeneutika dan psikologi sufistik, penelitian kualitatif ini menyimpulkan bahwa takwil yang dipraktikkan Ibn 'Arabī adalah proses dialektis antara teks suci dengan konteks psikis-spiritual, sehinggamampu menangkap ragam makna di dalam teks sebagai cerminan realitas multi-
\end{abstract}


dimensi.Penakwilan ini bersifat literal karena mengimani makna tekstual, sekaligus bersifat spiritual karena menjangkau singkapan batin.

Kata kunci: Takwil Ibn 'Arabī, Hermeneutika Sufistik, Konteks Psikis-Spiritual

\section{Pendahuluan}

Di antara berbagai pendekatan penafsiran, tafsir isyari ( $t a{ }^{\prime}$ wil șüfî)termasuk jenis yangpaling debatable. Sejak awal perkembangannya, otoritas dan keabsahan tafsir ini dipertanyakan, terutama oleh kalangan ahli hadis dan fiqh. Keraguan mereka terhadap otoritas tafsir isyari didasari oleh dugaan bahwa cara kaum sufi menafsirkan Alqurancenderung subjektif dan eksklusif, sertadinilai kurang memperhatikan prinsipprinsip penafsiran yang disepakati bersama. Mereka menuduh kaum sufi telah menjadikan Alquran tunduk pada ajaran-ajaran mistis yang sebenarnya tidak memiliki sandaran tekstual, baik dari Alquran maupun Sunnah, bahkan cenderung bertentangan dengan doktrin Islam. Maka dari itu, tak sedikit kalangan akademik yang mengeritik dan menolak tafsir isyari karena dianggap tidak otoritatif.

Di pihak lain, tak sedikit pula kalangan yang membela pendekatan isyari dalam menafsirkan Alquran. Mereka berargumen bahwa pemaknaan isyari tidak berarti menghapus makna tekstual Alquran. Hanya saja, di samping makna lahir tersebut, kaum sufi menangkap 'pesan' lain berdasarkan singkapan spiritual. Pesan lain ini lebih berorientasi pada nilai moral dan spiritual yang jurtu merupakan ruh agama Islam. Dengan demikian, kaum sufi justru memiliki kelebihan yang tidak dimiliki oleh ulama lain yang justru terjebak dalam formalisme bahasa agama, tanpa mampu menembus inti sarinya. Kaum sufisendiri memandang, makna eksoteris (zāhir) merupakan pintu masuk yang wajib dilalui untuk masuk kepada makna esoteris (bāțin), sehingga statusnya tidak bisa dinegasikan. Sebagaimana diibaratkan, orang yang sampai kepada makna batin tanpa melalui makna lahir, bagai orang yang masuk ke dalam rumah tanpa melalui pintu.

Ibn 'Arabi (W. 638 H.)adalah di antara kaum sufi yang ajaran dan takwil mistisnya dianggap paling kontroversial. Banyak kalangan yang menghujatnya, bahkan menuduhnya zindik karena berpaham wahdat al-wujüd yang dianggap sesat. Akibatnya, takwil sufistiknya, yang dianggap sebagai salah satu dasar pemikirannya, juga ditolak karena dinilai merupakan alat justifikasi bagi keyakinan batilnya, sehingga bersifat dekonstruktif terhadap tatanan teks suci dan dogma Islam. Namun tak sedikit pula yang membela dan mengagungkan Ibn 'Arabi. Bagi kalangan ini, Ibn 'Arabi adalah guru agung (al-shaykhal-akbar) yang ajaran tasawufnya banyak mempengaruhi generasi-generasi setelahya. Ibn 'Arabi bagi kalangan ini justru merupakan seroang sufi yang sangat taat pada tatanan dogma Islam. Pendekatan takwilnya pun diilustrasikan sebagian sarjana sebagai literalisme ketat.

Bertolak dari permasalahan di atas, artikel ini akan mendiskusikan tentang konstruksi epistemologi takwil Ibn 'Arabi melalui analisis terhadap asumsi-asumsi hermeneutis yang tesebar dalam berbagai karyanya, khususnya al-Futūhăt al- 
Makkiyyah. Pemilihan takwil Ibn 'Arabi sebagai objek penelitian didasari oleh pertimbangan bahwa Ibn 'Arabỉdikenal tokoh sufi falsafiyang di satu sisi dianggap sentral, namun di sisi lain juga dicap kontroversial. Oleh karenanya, hasil penelitian terkait tema seperti ini diharapkan dapat meluruskan berbagai kesimpangsiuran terhadap hakikat takwil Ibn 'Arabì secara khusus, dan tafsir isyari secara umum. Dalam menganalisis asumsi-asumsi hermeneutis Ibn 'Arabī, penulis menggunakan pendekatan hermeneutika yang digagas oleh Naṣr Hạmid Abū Zayd dan psikologi sufistik yang diperkenalkan oleh Robert Frager. Pendekatan pertama digunakan unt uk membaca proses pergeseran makna teks kepada makna signifikansi (maghzā), sedangkan pendektan kedua untuk membaca konteks psikis seorang sufi yang memungkinkannya menyingkapmakna spiritual.

\section{Relevansi Pembahasan}

Terdapat banyak tulisan yangsecara khusus membahas takwil Ibn 'Arabī. Berikut ini akan penulis utarakan beberapa penelitianterdahulu yang dianggap paling relevan. William C. Chittick menulis The Sufi Path of Knowledge: Ibn al-'Arabï's Metaphysics of Imagination. Di dalamnya, Chittick menyinggung bahwa takwil, sebagaimana yang digagas dan dipraktikan oleh Ibn 'Arabì, pada dasarnya merupakan kontekstualisasi teks Alquran berdasarkan ilmu limpahan yang dianugerahkan Tuhan. Otoritas Tuhan merupakan tolok ukur yang paling reliabledalam upaya memahami wahyu, bukan daya manusia yang terbatas. Oleh karenanya, untuk sampai pada pemahaman itu, manusia harus mengabdi secara total kepada Tuhan, membaca Alquran, dan menjalankan seluruh ketaatan sesuai dengan prinsip syariat. ${ }^{1}$ Concern utama Chittick adalah menunjukkan loyalitas Ibn 'Arabī terhadap prinsip lahir dan syariah. Oleh karenanya, ketika menjelaskan proses penafsiran, Chittick cenderung menjelaskannya secara normatif melalui inventarisasi ide-ide Ibn Arabỉ secara tematik, tanpa merumuskan konstruk epistemologi takwilnya.

Kecenderungan yang sama juga dilakukan oleh Michel Chodkiewicz dalam karyanya An Ocean Without Shore: Ibn Arabī, The Book, and the LaW. Pada dasarnya Chodkiewich ingin menegaskan ketaatan Ibn 'Arabi terhadap teks Alquran sebagai wahyu, yang dapat membuncahkan lautan makna tanpa jedabagi orang dengan tingkat spiritualitas tertentu. Namun bagi Ibn 'Arabī, makna lahir dan tuntutannya tidak pernah bisa dibatalkan, sehingga aspek syariah tidak bisa dilabrak di dunia ini. Justru hanya melalui syariah seseorang bisa menggapai kesempurnaan batin. ${ }^{2}$ Hampir sama dengan karya sebelumnya, concern utama karya ini adalah menampilkan kepatuhan Ibn 'Arabi terhadap prinsip tekstualisme dan hukum syariat, sebagai starting point bagi proses menyelami kedalaman spiritual.

\footnotetext{
${ }^{1}$ William C. Chittick, The Sufi Path of Knowledge: Hermeneutika al-Qur'ān Ibnu al-'Arabi, ter. Ahmad Nidjamdkk (Yogyakarta: Qalam, 2001), 17-18.

2 Michel Chodkiewicz, An Ocean Without Shore: Ibn Arabi, The Book, and the Law (New York: State University of New York Press, 1993), h. 35.
} 
Dari sudut pandang berbeda, Ian Almond menulissebuah artikel "The Meaning of Infinity in Sufi and Deconstructive Hermeneutics: When Is an Empty Text an Infinite One?." Di dalamnya, Almond membandingkan antara tawkil Ibn 'Arabī dengan hermeneutika dekonstruktif Derrida dengan menyimpulkan bahwa pada dasarnya tidak ada perbedaan antara dua jenis hermeneutika ini dalam hal kebebasan absolut dalam menafsirkan teks. Dalam hal Ibn 'Arabi, 'liberasi pemaknaan' ini dilatarbelakangi oleh pandangannya bahwa pentawilan Alquran adalah gerakan dari lahir ke batin, yang merupakan proses aktualisasi tak terbatas dari potensi makna al-Qura'n yang juga tak terhingga. ${ }^{3}$ Karya ini setidaknya berhasil membaca proses takwil Ibn 'Arabi dengan kacamata hermeuneutika dekonstruktif, namun tidak mengetengahkan berbagai instrumen,termasuk peran teks, yang secara epistemologis terlibatdalam proses pemaknaan tersebut.

Berbeda dengan Almond, Syed Rizwan Zamir dalam artikelnya "Tafsīral-Qur'ān bi-al-Qur'an: The Hermeneutics of Imitation and "Adab" in Ibn 'Arabi's Interpretation of the Qur'ān," dan Kautsar Azhari Noer dalam artikelnya "Hermeneutika Sufi: Sebuah Kajian atas Pandangan Ibn Arabi tentang Takwil Alquran," menegaskan bahwa takwil Ibn 'Arabi tidaklah bersifat dekonstruktif. Noer menjelaskan bahwa takwil Ibn 'Arabi merupakan penafsiran berdasar singkapan batin yang harus dimasuki melalui makna harfiah teks Alquran. ${ }^{4}$ Sementara Zamir menegaskan bahwa hermeneutika Ibn 'Arabì bersifat literal karena tidak pernah menolak makna lahir; makna batin tidak berada di luar kata literal, namun tepatya berada di dalamnya. ${ }^{5}$ Namun demikian, kedua karya ini pada dasarnya tidak secara langsung membahas epistemologi takwil Ibn 'Arabi. Elaborasi subtilnya lebih cenderung menginventarisir penjelasan dan penafsiran Ibn 'Arabī secara normatif, yang menguatkan asumsi kepaduan dimensi esoteris dan eksoteris dalam konsep takwilnya.

Tulisan yang secara komprehensif membahas takwil Ibn 'Arabì adalah karya Naṣr Ḥāmid Abū Zayd yang berasal dari disertasinya, yaitu Falsafat al-Ta'wīl: Dirāsah fî Ta'wīl al-Qur'ān 'Ind Muhyi al-Dīn bin 'Arabī. Karya ini berhasil memotret bahwa konstruk epistemologi takwil Ibn 'Arabi didasarkan pada kosmologi sufistiknya yang memandang multiplisitas alam. Takwil adalah mencerap teks al-Qur'an yang mencerminkan multiplisitas ini, sehingga muatan makna tekstidak tunggal, namun berlapis. ${ }^{6}$ Namun Abū Zayd tidak terlalu signifikan dalam menunjukkan peran teks dalam proses penakwilan.Di samping itu, pendekatan hermeneutika 'signifikansi' yang ditempuh oleh Nașr Hāamid kurang bisa membaca pengaruh kondisi jiwa seorang sufi

${ }^{3}$ Ian Almond, "The Meaning of Infinity in Sufi and Deconstructive Hermeneutics: When Is an Empty Text an Infinite One?," Journal of the American Academy of Religion, Vol. 72, No. 1 (Mar., 2004): h. 108.

${ }^{4}$ Kautsar Azhari Noer, "Hermeneutika Sufi: Sebuah Kajian atas Pandangan Ibn Arabi tentang Takwil al-Qur'an,” Kanz Philosophia, Vol. 2, No. 2 (Desember 2012): h. 309-3010.

${ }^{5}$ Syed Rizwan Zamir, "Tafsīr al-Qur'ān bi'l Qur'ān": The Hermeneutics of Imitation and "Adab" in Ibn 'Arabī's Interpretation of the Qur'ān," Islamic Studies, Vol. 50, No. 1 (Spring 2011): h. 9-10.

${ }^{6}$ Nașr Hāamid Abū Zayd, Falsafat al-Ta'wìl: Dirāsah fì Ta'wìl al-Qur'ān 'Ind Muhyi al-Dīn bin 'Arabī(Beirut: Dār al-Wihdah, 1983), h. 260-261. 
dalam proses negosiasi makna. Untuk membaca signifikansi jiwa itu, maka disertakan pula pendekatan psikologi sufistik seperti yang digagas oleh Robert Frager. Dengan demikian, tulisan ini menggunakan dua pendekatan utama; hermeneutika dan psikologi sufistik. Pendekatan pertama digunakan untuk membaca pergeseran makna dari makna lahir ke signifikansi batin, sedang pendekatan kedua untuk membaca konteks spiritual yangsecara signifikan melatarbelakangi proses pergeseran tersebut.

\section{Ibn 'Arabī: Antara Pro dan Kontra}

Ibn 'Arabi adalah sosok seorang sufi yang paling fenomenal sekaligus kontroversial. Bagi para pendukungnya, Ibn 'Arabi adalah guru spiritual yang paling agung (al-shaykh al-akbar) yang pengaruhnya sangat besar dalam perkembangan ilmu tasawuf. Ajaran mistiknya menyebar dengan cepat seiring penyebaran Islam, mulai dari Afrika, Balkan, sampai ke Indonesia dan China. Chittick menuturkan, alasanpenyebaran ajarannya secara masif ini adalah banyaknya ulama, dari berbagai disiplin ilmu yang berbeda, yang berhasi diyakinkan oleh kesahihan berbagai argumen dan keluasan wawasannya. Para ulama terpengaruh karena Ibn 'Arabīsenantiasa mengemukakan dalil-dalil yang kuat, yang bersumber dari berbagai khazanah keilmuan Islam, untuk menunjukkan kebenaran pandangan-pandangannya. ${ }^{7}$ Tak ayal, banyak ulama yang membela dan mengikuti ajarannya. Namun bagi para penentangnya, Ibn 'Arabïdigambarkan sebagai sosok sufi yang sesat, bahkan zindik (heresy) dan kafir, karena ajaran tasawufnya dinilai menyimpang dari ajaran tauhid Islam.

Dā'irat al-Ma'ārif al-Islämiyyah mencatat, diantara para ulama yang menentang ajaran mistik Ibn 'Arabī adalah Ibn Taymiyyah, Ibn al-Khayyāṭ, al-Ḥāiz al-Dhahabī, Ibn Iyyās, al-Taftazānī, 'Alì al-Qārī, dan al-Imām Jamāl al-Dīn bin Muhammad bin Nūr al-Din. Di pihak lain, tak sedikit pula ulama yang membela dan mendukung ajarannya. Di antara mereka adalah Majd al-Dīn al-Fayrūzabādi, Sirāj al-Dīn alMakhzūmī, Kamāl al-Dīn al-Zamlakānī, Syihāb al-Dīn al-Suhrawardi, Fakh al-Dīn alRāzì, Muḥammad al-Maghribī gurunya al-Imām al-Suyūṭi, al-Imām al-Suyūṭi sendiri, Taqiyy al-Dīn al-Subkī, Ibn Kamāl Bāsha, 'Abd al-Razzāq al-Qāshānī, dan sebagainya ${ }^{8}$ Bahkan sebagaimana dijelaskanoleh 'Abd al-Hafiz Farghali,ada beberapa ulama yang tadinya mengingkari dan memusuhi Ibn 'Arabi, namun setelah mengetahui hakikat ajarannya akhirnya memuji dan mengakui keunggulannya. Diantaranya adalah al-Ḥāiz al-Dhahabì yang secara jujur berkata: "saya kira Ibn 'Arabi sama sekali tidak berpegang pada kebohongan", dan 'Izz al-Dīn bin 'Abd al-Salām yang secara tegas menyatakan: "Muhyī al-Dïn Ibn 'Arabī adalah wali qut bo zamannya". ${ }^{10}$

\footnotetext{
${ }^{7}$ William C. Chittick, Ibn 'Arabi: Heir to the Prophets (Oxford: Oneworld, 2005), h. 2-3.

${ }^{8}$ Ibrahīm Zakkī Khurshīi, MüjazDà'irat al-Ma'ârif al-Islāmiyyah (Kairo: Markaz al-Shāriqah, 1998), Jilid I, h. 252.

${ }^{9}$ Dalam ajaran sufi, wali qutb merupakan derajat paling puncak pada hirarki kewalian. Seorang quṭb dikonsepsikan sebagai poros dan inti semesta, yang bermakna bahwa keberlangsungan alam raya secara metaforis bergantung pada kelangsungan hidup peribadinya. Wali qutb pada setiap zaman merupakan manifestasi al-Rūh al-Muhammadi bagi masa itu. Lihat, Jhon Renard, Historical Dictionary of Sufism (Maryland, Toronto, \& Oxford: The Scarecrow Press, 2005), h. 185.
} 
Ada beberapa sebab yang bisa menjelaskan mengapa Ibn 'Arabīinilai sangat kontroversial. Sebab yang paling utama adalah ajaran tasawufnya yang dianggap mengajarankan paham wahdat al-wujüd (kesatuan wujud).Meskipun secara eksplisit Ibn 'Arabi tidak pernah menggunakan istilah ini dalam karya-karyanya, namun pernyataan-pernyataannya dinilai mendukung paham tersebut, ${ }^{11}$ sehingga Ibn 'Arabi bagi kalangan akademik selalu identik dengannya. Bagi kalangan ulama ortodoks, konsep kesatuan wujud adalah paham yang sesat karena sama saja dengan mencampuradukkanantara Allah dengan alam ciptaan-Nya. ${ }^{12}$ Logikanya, jika wujud ini ada satu, maka artinya wujud Allah dan wujud alam adalah sama; wujud alam adalah wujud Allah dan wujud makhluk adalah wujud Khāliq. Paham seperti ini dianggap sesat karena bertentangan dengan prinsip tanzīh (ketidaksebandingan) Allah, yakni bahwa Allah tidak sebanding dengan apapun (mukhālafatuhu li-al-ḥawādith).

Namun demikian, bagi kalangan yang mendukungnya, terutama dari mayoritas kaumsufi, paham ini tidak identik dengan 'mencampurkan' Allah dengan alam ciptaan. Bagi kaum sufi, waḥdat al-wujüd lahir dari hasil perenungan yang mendalam terhadap berbagai fenomena alam dan berbagai kenikmatan yang merupakan tanda bagi keberadaan-Nya.Kekuasaan, keagungan, dan keindahan Allah tampak pada berbagai tanda ini sebagaimana efek sebab tampak pada akibat. Oleh karenanya, seorang sufi hanya melihat kekuasaan dan keagungan Allah di semua alam ini. ${ }^{13}$ Berdasarkan hal ini, segala sesuatu selain Allah dianggap tidak ada (ma'dūm) pada dirinya sendiri karena wujudnya bergantung sepenuhnya kepada wujud Allah. Dalam pemikiran Ibn 'Arabi, alam tidak memiliki wujud sendiri kecuali wujud pinjaman yang 'memancar' dari Allah. Tidak seperti dituduhkan para penentangnya, wahdat al-wujüdjuga menekankan sisi tanzīh, di samping sisi tashbïh (keserupaan). Jelasnya, dari sisi tashbīh, Allah identik dengan alam (meskipun tidak setara), dilihat dari sisi bahwa alam mencerminkan (manifestasi/tajalli) wujud-Nya, sebagaimana cahaya menunjukkan adanya matahari. Namun dari sisi tanzīh, Allah sama sekali berbeda dengan alam karena wujud-Nya mutlak dan tidak bergantung kepada apapun, sebagaimana matahari tidak bergantung kepada pancaran cahayanya. Hanya Allah yang ada, sedangkan selain-Nya ibarat cahaya yang wujudnya bergantung penuh pada matahari. Berdasarkan hal ini, tak heran jika Kautsar Azhari menyatakan bahwa wahdat al-wujüd adalah ekspresi tauhid paling tinggi, atau bisa jadi satu-satunya pemahaman tauhid yang benar. ${ }^{14}$

Sebab lain yang membuat Ibn 'Arabi mendapat penentangan keras adalah pendapatnya dalam Fuṣuṣ al-Hikam yang memuji bahkan menyatakan Fir’aun

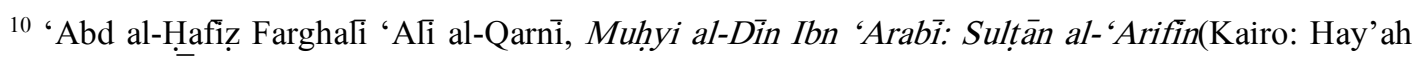
al-Mișriyyah al-‘'̄ंmmah li-Al-Kitāb, 1986), h. 170.

${ }^{11}$ William C. Chittick, Dunia Imajinal Ibnu 'Arabi: Kreativitas Imajinasi dan Persoalan Diversitas Agama, terj. Ahmad Syahid (Surabaya: Risalah Gusti, 2001), h. 27.

${ }^{12}$ Kautsar Azhari Noer, Tasawuf Perenial: Kearifan Kritis Kaum Sufi (Jakarta: Serambi, 2003), h. 146.

13 ،Abd al-Hafị Farghali 'Ali al-Qarni, Muhyi al-Dīn Ibn 'Arabī: Sultān al-'Arifin,h.156.

${ }^{14}$ Kautsar Azhari Noer, Tasawuf Perenial: Kearifan Kritis Kaum Sufi,h. 155. 
beriman. ${ }^{15}$ Namun demikian, 'Abd al-Hafíz Farghali meyakini bahwa pendapat ini tidak benar berasal dari Ibn 'Arabì, mengingat tak sedikit ulama yang menemukan bahwa dalam karya-karyanya, banyak pendapat asing yang disusupkan. ${ }^{16} \mathrm{Al}-\mathrm{Sha}$ 'rāni dalam alYawāqit wa-al-Jawāhir menemukan, dalam al-Futūhăt pada bab ke enam puluh dua, Ibn 'Arabī sendiri menyebutkan Fir'aun termasuk ahli neraka yang selamanya tidak akan pernah keluar darinya. Jika pun pendapat itu benar berasal darinya, maka sebenarnya bukan hanya Ibn 'Arabi yang berpendapat imannya Fir'aun. Menurut alSha'rānī, sebagian ulama salaf berpendapat bahwa imannya Fir'aun diterima ketika dia berkata, sebagaimana dituturkan oleh Q.S. Yunus [10]: 90: "Aku percaya bahwa tidak ada Tuhan melainkan Tuhan yang dipercayai oleh Bani Israil, dan saya termasuk orang-orang yang berserah diri (kepada Allah)". Bahkan Abū Bakr al-Bāqilānī berpendapat bahwa diterimanya iman Fir'aun lebih kuat dari segi dalil, karena tidak ada teks yang secara eksplisit menyatakan bahwa dia mati dalam kekafiran. ${ }^{17}$ Berdasarkan penjelasan ini, tampak bahwa pengingkaran dan hujatan terhadap Ibn 'Arabibiasanya dilatarbelakangi oleh faktor salah paham dan prasangka yang buruk.

Terlepas dari pemikiran mistiknya, Ibn 'Arabi juga dikenal karena akhlaknya yang mulia. Banyak orang yang sezaman denganya, baik dari kalangan sufi ataupun bukan, menghormati dan mengaguminya karena ketulusannya dalam mencari kebenaran, sikapnya yang wara, zuhud, dan penuh kasih sayang terhadap sesama. Farghali menuturkan, beliau memiliki banyak harta dan kekayaan, namun hal initidak sama sekali menghalanginya dari sifat zuhud.Tak sedikit raja yang menyukainya dan memberikan jaminan keamanan, kesenangan, dan kenikmatan, namun beliau tidak menginginkannya dan lebih memilih untuk membebaskan dirinya dari setiap ikatan. Ibn 'Arabī juga terkenal dengan kedermawanannya. Beliau memberikan semua pendapatan hariannya yang mencapai seratus tiga puluh dirham kepada kaum fakir miskin. Diriwayatkan, beliau mendapat hadiah rumah dari Kaisar Romawi seharga seratus ribu dirham. Ketika beliau tinggal di dalamnya, suatu hari ada pengemis yang meminta sedekah. Tanpa pikir panjang, Ibn 'Arabi memberikan rumahnya kepada si pengemis. Beliau berkata kepadanya: "saya hanya memiliki rumah ini. Terimalah rumah ini untuk anda." 18 Dengan demikian, keluhuran spiritualitas tidak memenjara Ibn 'Arabi di dalam menara gading, namun mengejewantah dalam karakternya yang peka terhadap permasalahan sosial.

\section{Takwil Sufidalam Perdebatan}

Dalam kosmologi sufistik, Tuhan mengejewantahkan Diri-Nya dalam tiga bentuk kitab suci. Pertama, kitab wahyu tertulis, yaitu Alquran; kedua, semesta (the universe);

15 Ian Almond, Sufism and Deconstruction: a Comparative Study fo Derrida and Ibn 'Arabi (London: Routledge, 2004), 85.

16، Abd al-Hafíz Farghali 'Ali al-Qarnī, Muhyi al-Dīn Ibn 'Arabì: Sultān al-'Arifīn, h. 164.

17 Al-Imām al-Sha'rānī, al-Yawāqīt wa-al-Jawāhīr fi-Bayān 'Aqā'id al-Akābir (Beirut: Dār Ihyā' al-Turāth al-'Arabī, t.t),h. 66.

18، Abd al-Ḥafị Farghali 'Ali al-Qarni, Muhyi al-Dīn Ibn 'Arabī: Sultān al- 'Arifīn, h. 80-81. 
dan ketiga adalah jiwa manusia. Seperti halnya Alquran, masing-masing dari kedua 'wahyu' ini bertabur tanda-tanda ( $\bar{a} y \bar{a} t)$ Tuhan. Ketiga entitas ini merujuk pada prinsip dan realitas yang sama, sebagai manifestasi Kebenaran Tertinggi (the Ultimate Haqq). ${ }^{19}$ Oleh karenanya, terdapat keselarasan di antara kitab tertulis (kitāb Allāh), alam raya (kitāb al-āfāq), dan jiwa manusia (kitāb al-anfus) karena ketiga entias ini merupakan teopani-teopani Tuhan. ${ }^{20}$ Jika semesta dan jiwa merupakan realitas multidimensi, maka kesimpulan logisnya, Alquran yang merupakan cerminan tertulis dari kedua entitas itu, memiliki karakakteristik yang sama dalam hal multiplisitas dimensi maknanya.

Berdasarkan hal di atas, tak sedikit ulama, seperti Ibn Taymiyyah, yang salah paham terhadap tafsir isyari, sehinggamenyamakan takwil isyari dengan takwil batini yang dianggap menolak dan tidak mengimani dimensi lahir Alquran. ${ }^{21}$ Dari kalangan orientalis, pendapat yang sama dilontarkan oleh Nicholson. Menurutnya, komposisi Alquran pada dasarnya tidak bisa menjadi landasan bagi ajaran sufistik. Namun dengan mengadopsi perangkat takwil dari golongan $S h \bar{i}$ 'ah, kaum sufi mampu menjustifikasi ajaran-ajaran mistis mereka, dengan cara mentakwilkan teks-teks suci sesuai dengan kepentingan-kepentingan mereka. ${ }^{22}$ Bagi kaum sufi, setiap ayat bahkan setiap kalimat dalam Alquran memuat makna spiritual di sebalik rangka tekstualnya. Makna ini hanya Allah singkapkan bagi orang-orang pilihan, melalui hati-hati mereka, ketika mengalami ektase-spiritual. Dengan asumsi seperti ini, setiap sufi akan dengan mudah menemukan justifikasi tekstual dari Alquran bagi setiap pendapat dan ajarannya, bagaimanapun liarnya. ${ }^{23}$

Di tempat lain, Goldziher menegaskan bahwa kaum sufi mengunakan mekanisme interpretasi simbolik sebagai alat justifikasi bagi paham-paham yang sesuai dengan noktah-noktah Alquran dan Sunnah. ${ }^{24}$ Fazlur Rahman menguatkan bahwatafsir isyari hanyalah 'polesan tipis' terhadap berbagai pemikiran asing yang tidak kompatibel dengan ajaran Alquran. ${ }^{25}$ Tafsir isyari dengan demikian merupakan sarana bagi upaya rekonsiliasi antara teks-teks Islam dengan pemikiran-pemikiran 'luar' itu. Secara lebih spesifik, al-Jābiriberpendapat bahwa mekanisme takwil sufi adalah perangkat yang sebenarnya telah digunakan oleh berbagai aliran gnostik pada hanyak tradisi. Kaum sufi mengadopsi takwil gnostik yang berasal dari tradisi hellenisme dan filsafat mistik-

${ }^{19}$ Wiliam C. Chittick, "Time, Space, and the Objectivity of Ethical Norms: The Teachings of Ibn al-'Arabī," Islamic Studies, Vol. 39, No. 4, Special Issue: Islam and Science (Winter 2000): h. 585.

${ }^{20}$ Sajjad H. Rizvi, "The Existential Breath of al-raḥmān and the Munificent Grace of al-rahīm : The Tafsīr Sūrat al-Fàtiḥah of Jämi' and the School of Ibn 'Arabī,"Journal of Qur'anic Studies, Vol. 8, No. 1 (2006): h. 58-59

${ }^{21}$ Muhammad al-Sayyid al-Jiliand, al-ImāmIbn Taymiyyah wa Mauqifuhu min Qaḍiyyat al-Ta'wīl (Jeddah: Maktabah 'Ukaz, 1983), h. 209.

22 Reynold A. Nicholson, Studies in Islamic Mysticism (London: Curzon Press, 2005), h. 60-61.

${ }^{23} \mathrm{Abū}$ 'Abd al-Raḥmān al-Wāṣifì, Mawāzīn al-Süfiyyah (Alexandria: Dār al-Īmān, 2006), h. 58

${ }^{24}$ Ignaz Goldziher, Mazhab Tafsir: dari Aliran Klasik Hingga Modern, terj. M. Alaika Salamullah, dkk. (Yogyakarta: eLSAQ Press, 2006), h. 217.

${ }^{25}$ Fazlur Rahman, Islam and Modernity: Transformation of an Intellectual Tradition (Chicago: The University of Chicago Press, 2009), h. 3. 
hermetisme, dan kemudian digunakan untuk menundukan teks-teks agama terhadap ajaran-ajaran mereka, sehingga 'rangka' teks suci menjadi penuh muatan gnostik. ${ }^{26}$ Berbeda dengan kalangan ulama eksoterik yang mendekati teks secara objektif dengan memfokuskan pada aspek historisitas dan linguistik teks, pendekatan sufistik merupakan pedekatan personal berdasarkan pengalaman mistis-subjektif, yang sama sekali terlepas dari kerangka historis maupun signifikansi rasio. ${ }^{27}$

Terkait dengan konsep takwil Ibn 'Arabi secara khusus, beberapa akademisi juga menilainya sebagai liberasi pemaknaan teks Alquran berdasarkan pengalaman mistik. Corbin berpendapat, takwil yang dipraktikan Ibn 'Arabi pada dasarnya merupakan upaya pemahaman simbolik yang menggubah segala sesuatu menjadi simbol. Mekanisme ini mengasumsikan adanya esensi dalam segala sesuatu yang terlepas dari penalaran logika mapupun persepsi indrawi. Proses Interpretasi ini terkait dengan alam ide (the world of correspondences), di mana organ pengetahuannya merupakan imajinasi aktif. ${ }^{28}$ Takwil ini mengisyaratkan simbol-simbol yang terus berkembang (flowering), sebagai hasil yang diproduksi oleh imajinasi aktif itu. Karena daya imajinasi ini pada dasarnya termasuk entitas dunia ide yang mempelantarai alam spiritual murni dengan alam empiris-historis, maka takwil sufisik yang bertumpu pada daya imajinasi ini secara esensial tidak men-'diami' (inhabit) realitas kehidupan seharihari. Sehingga pada tataran aksiologis, daya jiwa dan spiritual seorang sufi seringkali memberontak tatanan norma agama. ${ }^{29}$

Secara lebih tegas, Almond menyatakan bahwa takwil Ibn 'Arabi pada dasarnya bersifat dekonstruktif. Multiplisitas makna teks merupakan titik temu antara tafsir Ibn 'Arabi dengan hermeneutika dekonstruktif, karena keduanya mengimani kebebasan absolut dalam memperlakukan teks. ${ }^{30}$ Keterbukaan hermeneutika dekonstruktif yang memandang teks sebagai mesin makna (meaning-machine) sehingga secara konstan mampu menghasilkan makna-makna baru, pada dasarnya tidak berbeda efeknya dari keterbukaan takwil Ibn 'Arabi terhadapAlquran. Ketidakterbatasan Pengarangnya (Tuhan) 'meledakan' (explodes) Alquran, melepaskannya sekaligus kepada semua arah, sehingga membuatnya mampu mengatakan hal tak terbatas kepada tujuan yang juga tak terhingga. ${ }^{31}$ Dengan demikian takwil yang diterapkan Ibn 'Arabi merupakan teknik penafsiran mistis-esoteris yang mengasumsikan teks memiliki muatan makna 'dalam' yang tak terhingga. Alih-alih menafsiran teks, takwil justru melepaskannya, menggiring pembaca kepada tingkatan makna-makna baru yang lebih tinggi. ${ }^{32}$

26 'Abid al-Jābiri, Takwīn al-'Aql al-'Arabi (Beirut: Markaz Dirāsāt al-Wahdah al-'Arabiyya, 2002), h. 271.

${ }^{27}$ Maryam Musharaf, "a Study on the Sufi Interpretation of Qur'an and the Theory of Hermeneutic," al-Bayan Journal, Vol. 11, No. 1 (June 2013):h. 34.

${ }^{28}$ Henry Corbin, Creative Imagination in The Sufism of Ibn 'Arabi ( New York: Routledge, 2008), h. $25-26$

${ }^{29}$ Henry Corbin, Creative Imagination in The Sufism of Ibn 'Arabi, h. 31.

${ }^{30}$ Ian Almond, Sufism and Deconstruction: a Comparative Study, h. 74.

${ }^{31}$ Ian Almond, Sufism and Deconstruction: a Comparative Study, h. 65-66.

${ }^{32}$ Ian Almond, "The Meaning of Infinity in Sufi and Deconstructive Hermeneutics: When Is an Empty Text an Infinite One?," h. 101. 
Di pihak lain, tak sedikit pula kalangan akademik yang membela dan mendukung tafsir isyari, termasuk takwil Ibn 'Arabi..Kalangan ini berpendapat bahwa pemaknaan isyari tidak mengeliminasi tatanan lahir Alquran, namun memberikan nuansa makna berbeda yang justru merupakan makna turunan dari makna literalnya. Omaima Abū Bakar menjelaskan,karakter isyari (symbolic character) pada bahasa Alquran merupakan hal tipikal yang bisa kita temukan pada semua isinya.Hal ini karena proses pewahyuan hakikatnya adalah 'mengulangi' manifestasi Tuhan, sehingga sebagai implikasinya, teks suci mengungkapkan berbagai tingkatan makna. Interpretasi makna batin didasarkan pada kandungan simbolisme-metafisis kandungan Alquran, ditambah multiplisitas makna kata-katanya. Muatan internal ini berkaitan erat dengan dimensi eksternal, sebagaimana dimensi eksternal bersandar pada muatan internal. ${ }^{33}$ Kedua sisi lahir-batin dengan demikian merupakan suatu hal yang berelasi secara vertikal, serta tidak saling menegasikan.

Kaum sufi sendiri menolak jika pendekatan penafsiran mereka dikategorikan sebagai takwil băținiataupun penafsiran bebas yang melabrak ketentuan-ketentuan eksoterik Alquran. Dalam kitabnya Faụā'ị̆ al-Bātiniyyah, Al-Ghazāli (W. 505 H.) menjelaskan, perbedaan asasi antara kaumsufi dan Bạtiniyyah adalah bahwa meskipun kalangan sufiberorientasi pada upaya mengungkap makna spiritual dibalik teks, namun mereka masih menerima makna eksternal teks. Adapun Bāținiyyah, mereka hanya percaya pada aspek batin teks, dengan tujuan membatalkan tuntutan-tuntutan syariat. ${ }^{34}$ Berdasarkan penjelasan ini, Campanini menegaskan, interpretasi sufistik merupakan proses evolusi penafsiran menuju tingkatan makna yang selalu lebih esoterik. Namun hal ini tidak selaras dengan model interpretasi mistis-gnostik yang dipraktikkan oleh sekte Ismā'iliyyah. Esoterisme dalam tafsir sufimerupakan pengetahuan esensial yang berasal dari Tuhan, yang menunjukan jalan spiritual melalui bahasa eksternal teks, agar dengannya seseorang dapat memahami rahasia keimanan dan kepatuhan yang tersembunyi dalam rangka tektual. Dengan demikian, tafsir isyari merupakan hasil penyingkapan iluminatif dan tidak mungkin terjadi kontradiksi di dalamnya antara dimensi esoterik dan dimensi eksoterik. ${ }^{35}$

Di tempat lain, Schimmel mengakui bahwametode hermeneutika sufistik bermacam-macam, mulai dari interpreatsi verbal yang sederhana hingga penafsiran simbolik dan alegoris, namun bagaimanapun, tidak menampik nilai dari makna eksternal Alquran. ${ }^{36}$ Akibat asumsi awal yang didapat ketika meneliti ungkapanungkapan mistik kaum sufi, para peneliti Barat seringkali mengangap kaum sufi sebagai perwujudan gerakan yang terlepas total dari tuntutan-tuntutan legal-etis dalam

\footnotetext{
${ }^{33}$ Omaima Abū Bakr, "The Symbolic Function of Methapor in Medieval Sufi Poetry: The Case of Shustari," Alif: Journal of Comparative Poetics, No. 12, Metaphor and Allegory in the Middle Ages (1992): h. 42.

${ }^{34}$ Abū Hāamid al-Ghazāili, Faḍāḥ al-Batiniyyah (Beirut: Maktabat al-‘Așriyyah, 2011), h. 21-22.

${ }^{35}$ Massimo Campanini, The Qur'ān: The Basics, trans. Oliver Leaman (London and New York, Routledge, 2007),h. 89

36 Annemarie Schimmel, Mystical Dimensions of Islam (North Calorina: The University of North Carolina Press, 1975), h. 25.
} 
Islam dan tidak lagi memperdulikan formalitas agama. Namun bagi Schimmel, penghukuman seperti ini terlalu terburu-buru dan kurang tepat. Karena bagaimanapun, dalam keyakinan kaum sufi, syariat sebagai representasi dimensi eksternal Alquran, justru merupakan sumber yang darinya capaian spiritual berasal. Kaum sufi tidak menanggalkan bentuk-bentuk ritual agama, namun justru memaknainya secara lebih dalam (interiorizing). ${ }^{37}$

Tentang takwil Ibn 'Arabi secara khusus, tak sedikit juga kalangan akademik yang membelanya sebagai takwil yang reliable (ta'wīl sā'igh) karenadianggap selalu menghormati prinsip tekstualitas. Chittick dalam hal ini menegaskan bahwa interpretasi sufisik yang dipraktikkan oleh Ibn 'Arabì pada dasarnya tidak menolak makna literal. Makna batin merupakan makna tambahan berdasarkan penyingkapan ilahiyyah, yang bisa dipercaya sepanjang tidak berseberangan dengan makna literal. Hal ini mengingat fakta bahwa otoritas Tuhan merupakan tolok ukur utama dalam upaya memahami hakikat wahyu, bukan daya manusia yang terbatas. Oleh karenanya, untuk sampai pada pemahaman itu, manusia harus mengabdi secara total kepada Tuhan, membaca Alquran, dan menjalankan seluruh ketaatan sesuai dengan prinsip syariat. $^{38}$

Ibn 'Arabi sendiri dalam al-Futụhăt al-Makkiyyah menjelaskan urgensi prinsip tekstualitas dalam takwilnya dengan mengatakan, "jika terdapat ayat Alquran ataupun hadis dengan suatu lafal bahasa tertentu, maka prinsip utama (dalam menafsirkan-nya) adalah pemaknaan apa adanya menurut kaidah bahasa Arab. Namun ketika Tuhan menggunakan lafal ini bukan dalam pengertian bahasa-nya, (melainkan sebagai istilahistilah syariat) seperti kata salat, wudu, haji, dan zakat, maka yang menjadi landasan adalah apa yang dikosepsikan dan ditetapkan Tuhan sebagai Shāri' (pembuat hukum). '39 Maka tak heran jika Chodkiewiczmenyebut pendekatan takwil Ibn 'Arabisebagaibentuk literalisme ketat (literal strictness). ${ }^{40}$ Dia menambahkan, jika kita melihat Ibn 'Arabi kerap menyalahkan kaum legalis-formalistik yang hanya mementingkan rangka eksoterik Alquran, namun nyatanya dia lebih keras terhadap kalangan Bātiniyyah yang hanya menganggap makna simbolik-alegoris dan menolak makna eksternal. Oleh karena itu, kebahagian sejati bagi Ibn 'Arabì hanya digapai oleh orang yang memadukan makna lahir dengan makna batin. Sedikit pengetahuan tentang batin memalingkan seseorang dari zahir, sedangkan banyak pengetahuan tentang batin membuatnya kembali kepada zahir. ${ }^{41}$

Mengingat bahwa takwil Ibn 'Arabì pada dasarnya selaras dengan eksoterismeAlquran, Rizwan Zamir menyebutnya sebagi hermeneutika literalismespiritual. Jika bagi kaum sufi setiap huruf Alquran yang berbahasa Arab diyakini

${ }^{37}$ Annemarie Schimmel, Mystical Dimensions of Islam, h. 106.

${ }^{38}$ William C. Chittick, The Sufi Path of Knowledge: Hermeneutika al-Qur'ān Ibnu al-'Arabi,,h. 1718.

${ }^{39}$ Ibn 'Arabì, al-Futūhāàt al-Makkiyyah (Beirut: Dār Ihyā' al-Turāth al-'Arabì, 2010), Jilid IV, h. 106.

${ }^{40}$ Michel Chodkiewicz, An Ocean without Shore: Ibn 'Arabī, The Book, and the Law, h. 24.

${ }^{41}$ Michel Chodkiewicz, An Ocean without Shore: Ibn 'Arabî, The Book, and the Law, h. 24. 
sebagai murni kalam Tuhan, yang mencerminkan multiplisitas manifestasi-Nya yang tak terbatas, maka cara paling masuk akal untuk menyingkap mutliplisitas itu mesti beranjak dari rangka tekstual Alquran itu sendiri. Literalisme dalam konteks ini tidak berarti bahwa hanya ada satu kemungkinan makna dalam teks.Namun pembacaan secara literal terhadap Alquran secara bersamaan 'membuncahkan' pluralitas makna dari dalamnya. ${ }^{42} \mathrm{Hal}$ ini karena di samping faktor singkapan ruhani, konstruksi tekstual Alquran sendiri, termasuk karakteristik bahasa Arab yang kaya kosa-kata dan struktur gaya bahasa Alquran yang kompleks, secara inhrernt memungkinkan ragam penafsiran.

Berdasarkan elaborasi di atas, dapat disimpulkan bahwa takwil sufistik, termasuk takwil Ibn 'Arabi, merupakan upaya memahami apa yang Allah maksud dalam konstruksi tekstual kitab-Nya berdasarkan ilhām ilahi, bukan malah memaksakan berbagai unsur asing memaknai Alquran. Makna spiritual adalah karunia Allah yang diberikan kepada orang-orang pilihan, ketika mereka membaca, merenungkan dan mengamalkan ajaran-ajaran Alquran secara terus-menerus. Dengan demikian, makna spiritual selalu merupakan makna derivatif dari makna tekstual, bukan malah menghapus ataupun menggantikannya.Kesalahpahaman mengenai hakikat tafsir isyari timbul karena pemahaman yang tidak menyeluruh, di samping pra-konsepsi negatif terhadap ajaran dan amalan kaum sufi.Takwil sufistik mempostulasikan, literaslisme dan spiritualitas berdialektika dalam menegosiasikan makna, sehingga melahirkan dualisme lahir-batin yang membentuk spektrum makna yang saling melengkapi. Implikasi epistemologis seperti ini terlihat jelas pada loyalitas kaum sufi terhadap dimensi syariatsecara khusus dan sistem dogma Islam secara umum.

\section{KonstruksiEpistemologi Takwil Ibn 'Arabỉ Teks Suci sebagai Cerminan Realitas Multi-Dimensi}

Pandangan seorang sufi terhadap teks Alquran terkait erat dengan kosmologi sufi yang yang melihatmultiplisitas alam. Dalam pandangan sufi, teks suci sebagai firman Tuhan ibarat cermin yang memantulkan berbagai realitas tersebut. Takwilmerupakan instrumen yang diasumsikan dapat menjembatani antara konstruksi teks suci dengan penyaksiandimensi spiritual. ${ }^{43}$ Oleh karenanya, teks suci bukan merupakan entitas stagnan yang hanya memiliki satu kemungkinan makna, namunmerupakan cermin jernih yang dapat memantulkan kompleksitas alam tersebut, sehingga memiliki ragam makna. Penyingkapan batin dari dalam teks hanya akan didapat oleh mereka yang telah terlebih dahulu menjernihkan mata hatinya dari berbagai debu dan kotoran yang menggangu penglihatan mata hati. Konstruksi lahir teks merupakan pijakan dasar

${ }^{42}$ Syed Rizwan Zamir, “Tafsiral-Qur'ān bi al-Qur'ān: The Hermeneutics of Imitation and "Adab" in Ibn 'Arabi's Interpretation of the Qur'an,': h. 9-12.

43 Asep Salahudin, "Konstruksi Epistemologi Tasawuf," dalam dalam Tarekat Qādiriyyah Naqshabandiyyah Pondok Pesantren Suryalaya Membangun Peradaban Dunia, ed. Ajid Tohir (Suryalaya: Mudawaha warohmah Press, 2011), h. 90. 
interpretasi, namun batasan antara teks dan pemaknaan selalu bergeser sesuai dengan horizon pengalaman spiritual seorang sufi. ${ }^{44}$

Alquran bukan merupakan teks linguistik-historis semata yang maknanya terpenjaraoleh berbagai aturan dan kaidah kebahasaan. Bahasa Arab sendiri yang merupakan bahasaAlquran, hanyalah setitik renik pada hamparan manifestasi kalam Tuhan yang tak berbatas. Alquran adalah firman Tuhan, sebagaimana hamparan realitas merupakan kata-kata-Nya. Sehingga yang paling penting bagi seorang sufi bukan memahami Alquran melalui perspektif bahasa, namun mendengarkan Pembicaranya secara langsung, dengan menyaksikan manifestasi-manifestasi kalam Pewicara, yang bertabur pada semesta wujud dan dalam kandungan teks secara bersamaan. ${ }^{45}$ Dengan demikian, pemaknaan sufi terhadap firman Alquran merupakan kombinasi antara 'mendengarkan' sabda-sabda wujud di alam luar dengan mendengarkan sabda-sabda jiwa dari dalam, yang sama-sama berstatus sebagai manifestasi kalam ketuhanan.

Tak terkecuali pada kasus Ibn 'Arabì, pandangan kosmologi sufistik merupakan salah satu basis utama bagi asumsi hermeneutisnya.Ibn 'Arabi membagi realitas sebagaimana dikutip oleh Nașr Hāamid Abū Zayd dalam bukunya Falsafat al-Ta'wīl: Dirāsah fì Ta'wìl al-Qur'ān 'Ind Muhyi al-Dīn bin 'Arabī, menjadi empat tingkatan. Pertama, 'ālam al-mulk wa al-shahādah, yakni alam fisik-empiris. Kedua, 'ālam alghayb wa al-malakūt, yakni alam batin-spiritual. Ketiga ‘ālam al-barzakh wa al-jabarūt, yakni alam pelantara, yang disebut pula sebagi alam batasan ('âlam al-hadd). Dan keempat adalah 'ālam al-asmā' al-ilāhiyyah (alam nama-nama Tuhan), yang merupakan alam gaibyang tertutup absolut (al-barzakh wa al-kiyāl al-muțlaq), yang disebut juga sebagai alam tujuan final ( 'ālam al-matla ). ${ }^{46}$ Bertolak dari asumsi empat tingkatan kosmos ini, Ibn 'Arabī memandang bahwa segala sesuatu di alam wujud memiliki dimensi zāhir, bătin, hadd, dan mațla'Dalam konteks ini, Ibn 'Arabi menjelaskan, "tak ada sesuatu pun melainkan memiliki dimensi zăhir, bātin, ḥadd (batasan), dan matla' (tujuan final). Zāhir-nya adalah apa yang engkau tangkap dari bentuk fisiknya. Bătin adalah apa yang engkau cerap dari efek substansi batin yang menguasai lahirnya. Hadd adalah apa yang membedakan-nya dengan entitas lain. Sementara matla'-nya adalah apa yang memungkinkan engkau sampai kepada (hakikat)-nya ketika engkau berhasil menyingkap tabirnya." ${ }^{47}$

Manusia misalnya, memiliki dimensi zahir, yaitu bentuk fisik yang dapat dipersepsi secara indrawi. Sementara dimensi batin manusia adalah ruh yang berkuasa atas bentuk fisik-nya. Manusia juga mempunyai hadd (batasan), yakni hal yang membedakannya dengan binatang, tumbuhan, dan benda mati. Sedangkan matla manusia merupakan tujuan akhir keberadaannya. Konsepsi empat dimensi wujud ini

${ }^{44}$ Sajjad H. Rizvi, “ The Existential Breath of al-Raḥmān and the Munificent Grace of al-Rahīm: The TafsirSürat al-Fātiḥa of Jāmì and the School of Ibn 'Arabì,"h. 59.

${ }^{45}$ Nașr Hāmid Abù Zayd, Falsafat al-Ta'wỉl, h. 275

${ }^{46}$ Nașr Ḥ̄amid Abū Zayd, Falsafat al-Ta'wỉl,h. 277.

${ }^{47}$ Nașr Hāmid Abū Zayd, Falsafat al-Ta’wīl,h. 276. 
kemudian diberlakukan pada teks Alquran, sehingga menjadikannya memiliki tingkatan-tingkatan makna, yang saling terhubung satu sama lain. Kenyataan ini jika dilacak secara geneologis, selaras dengan sabda Nabi yang mengatakan, "setiap ayat memiliki dimensi zahir dan batin, setiap kata mempunyai batasan, dan setiap batasan memiliki tujuan final (matla ')."48

Multiplisitas realitas memantul pada cara Ibn 'Arabi membaca teks suci, sehingga memungkinkannya untuk menyingkap ragam makna. Makna, dengan demkikan, bukan sebatas apa yang tampak pada rangka tekstual Alquran, namun juga mencakup rahasia-rahasia ilāhiyyah yang terpendam di kedalaman teks. Namun seperti halnya keterpantulan bentuk-bentuk material pada cermin bergantung pada kejernihan cermin, begitu pula terpantulnya realitas-realitas gaib pada jiwa menyaratkan kejernihan dan kecuian jiwa dari noda-noda dosa dan akhlak tercela. ${ }^{49}$ Hanya jiwa yang sucilahyang akan mampu menyingkap kualitas-kulaitas spiritual ketika membaca Alquran dari kedalaman horizonnya. Mengenai status ontologis pandangan ini, Kristin Zahra Sands menegaskan bahasa simbolik-metaforis yang digunakan kaum sufi dalam penafsiran Alquran bukan sekedar bentuk fantasi belaka, namun merupakan realitas objektif yang lahir dari hubungan dialektis antara pemikiran dan tatanan kosmos. Gaya bahasa dan diskursus yang digunakan dalam penafsiran sufistik mungkin saja tampak seperti metaforis, namun hakikat-nya ia merupakan deskripsi akan pengalaman langsung yang mereka alami dalam alam spiritual. ${ }^{50}$

Berdasarkan penjelasan di atas, dapat disarikan bahwa teks Alqurandalam pandangan Ibn 'Arabī merupakan lautan makna yang mecerminkan multi-lapisan semesta realitas. Jiwa sebagai indra batin mampu mendapatkan berbagai rahasia itu melalui pendekatan simbolik-alegoris, setelah terlebih melalui serangkaian proses penyucian dan pembersihan hati. Dengan demikian, Alquran tidak sebatas apa yang tampak pada rangka teksual, namun lebih dari itu, merupakan representasi kalam Tuhan yang abadi, yang mencakup-pantulkan seluruh lapisan realitas ciptaan-Nya. Lapisan makna-makna Alquran bervariabel mengikuti runtutan tangga-tangga realitas, mulai dari tingkatan paling lahir, sampai berujung pada makna paling batin.

\section{Prinsip Tekstualitas sebagai Basis 'Objektifisme’}

Setiap mufasir, apa pun latar belakang dan spesifikasi keilmuannya, dituntut menguasai berbagai perangkat linguistik maupun stilistik, yang memungkinkannya melakukan analisis tektual-linguistik terhadap Alquran, tak terkecuali kaum sufi. Mohammad Hashim Kamali menjelaskan, berbagai prinsip dan ketentuan teknis yang membahas permasalahan kata beserta berbagai pengguanaan dan klasifikasinya (dalālat al-alfã) berfungsi sebagai instrumen penting untuk mendapatkan pengertian yang

${ }^{48}$ Ibn 'Arabì, al-Futūhạăt al-Makkiyyah, Jilid I, h. 285.

${ }^{49} \mathrm{Ja}$ 'far al-Ṣbhānī, al-Madkhal ilā al-'Ilm wa al-Falsafah wa al-Ilāhiyyāt: Nazariyyat al-Ma' 'rifăh (Beirut: al-Dār al-Islāmiyyah, 1990), h. 179-180.

${ }^{50}$ Kristin Zahra Sands, Sufi Commentaries on the Qur'ân in Classical Islam, (New York: Routledge, 2006), h. 2. 
'benar' mengenai sistem ajaran Islam. ${ }^{51}$ Mengingat urgensi penguasaan dalālat al-alfàz, maka tak mengherankan jika buku-buku 'ulüm al-qur'ān mencantumkan disiplin ilmu usūl al-fiqh sebagai salah satu disiplin ilmu yang wajib dikuasai oleh seorang mufasir, karena seperti ditegaskan pula oleh M. Quraish Shihab bahwa uṣūl al-fiqh merupakan salah satu ilmu instrumental yang sangat dibutuhkan dalam rangka memahami Alquran, khususnya persoalan lafad dalam kaitannya dengan makna lafad itu, baik ketika berdiri sendiri sebagai satu kosakata, ataupun setelah terangkai dalam satu susunan kalimat. ${ }^{52}$

Mengenai urgensi tatanan tekstual Alquran dalam takwil sufi, al-Ḥārith alMuhāāibī (w. 243 H.) menjelaskan bahwa sebelum memahami kitab Alquran, seorang sufi harus terlebih dahulu menguasai berbagai ilmu dan kaidah-kaidah, yang telah digariskan oleh para ulama dalam disiplin 'ulūm al-Qur'ān dan uṣūl al-fiqh, seperti ilmu nāsikh dan mansūkh, muhkkam dan mutashābih, uslüb taqdìm dan ta'khïr, makna 'ām dan khāṣs, kata-kata langka (gharīb al-lughah), dan lain-lain. Al-Muhāāibì juga menandaskan, sebagian teks suci ada yang tidak bisa diketahui makna-nya kecuali dengan penjelasan al-Sunnah ataupun Ijmā',ada pula yang hanya bisa dipahami ketika ditinjau aspek intertekstualitasnya. ${ }^{53}$ Berdasarkan penjelasan ini, pemahaman yang dikehendaki oleh kaum sufi adalah pemahaman spiritual yang berlandaskan tatanan eksoterik Alquran, sehingga pemaknaannya diharapkan tidak mengacau semena-mena.

Urgensi dimensi eksoterik dalam interpretasi Alquran tak terlepas dari pandangan keterpaduan antara aspek mistis dengan aspek dogmatis dalam Islam. Upaya memisahkan elemen spiritual dari konstruksi ajaran agama yang berperan sebagai penyokong eksternal, justru berakibat fatal, karena berpotensi menghancurkan sendi-sendi spiritualitas itu sendiri. Hal ini karena bagaimanapun, mistisisme harus bergantung pada bentuk ekternal ajaran agama, agar tidak kehilangan landasan objektifitasnya. ${ }^{54}$ Tidak seperti pendekatan bătin̄i, hubungan antara domain 'luar' (outward) dan domain 'dalam' (inward) dalam ajaran tasawuf secara keseluruhan, merupakan hubungan saling melengkapi. Eksoterisme dianalogikan sebagai garis sebuah lingkaran, sementara esoterisme diserupakan sebagai pusat lingkaran tersebut. Jarak tempuh dari garis terluar menuju pusat merupakan jalan mistis yang disebut sebagai tarekat, yang mampu menghubungkan tampilan eksternal kepada rahasia batin. ${ }^{55}$

Fakta yang terkadang luput dari kebanyakan kalangan akademik adalah bahwa Ibn 'Arabi dalam konsep dan praktik takwilnya sangat menghargai eksoterisme Alquran. Mengenai hal ini, Ibn ‘Arabīmemaparkan,

51 Mohammad Hashim Kamali, The Principles of Islamic Jurisprudence (Geneva: Islamic Texts Society, 1989), h. 86-87.

${ }_{52}$ M. Quraish Shihab, Kaidah Tafsir (Ciputat: Lentera Hati, 2013), h. 155-156.

${ }^{53}$ Al-Ḥārith bin Asad al-Muhāsibī, al- 'Aql wa Fahm al-Qur'ān (Beirut: Dār al-Fikr, 1971), h. 325326.

54 William Stodart, Outline of Sufisme: The Essentials of Islamic Spirituality (Indiana: World Wisdom, 2012), h. 3

${ }^{55}$ William Stodart, Outline of Sufisme: The Essentials of Islamic Spirituality, h. 4-5. 
Jika terdapat ayat Alquran ataupun hadis dengan suatu lafal bahasa tertentu, maka prinsip utama (dalam menafsirkan-nya) adalah pemaknaan apa adanya menurut kaidah bahasa Arab. Namun ketika Tuhan menggunakan lafal ini bukan dalam pengertian bahasa-nya, (melainkan sebagai istilah-istilah syariat) seperti kata salat, wudu, haji, dan zakat, maka yang menjadi landasan adalah apa yang dikosepsikan dan ditetapkan Tuhan sebagai Shäri' (pembuat hukum).... Semua bentuk perintah shar' (awāmir al-shar') dipahami sebagai makna kewajiban (melakukan) dan semua bentuk larangan dipahami sebagai makna keharaman, selama tidak ada indikasi kondisi tertentu yang membelok-kan makna kewajiban ini menjadi anjuran (al-nadb) ataupun kebolehan (al-ibăhah). Begitu pula bentuk larangan (tidak bermakna haram), jika terdapat indikasi yang menjadikan-nya bermakna kurang baik (karāhah)..$^{56}$

Jika dianalisis secara seksama, pernyataan Ibn 'Arabi di atas memiliki kesesuaian dengan kaidah inti penafsiran yang dibahas dalam literatur 'usūl al-fiqh dan 'ulüm alqur'ān. Hal ini sebagaimana ditandaskan oleh Quṭb al-Raysūni bahwa para ulama uṣūliyyin sepakat bahwa yang menjadi pondasi inti dalam menafsirkan Alquran adalah bahwa teks Alquran harus dimaknai berdasarkan pengertian doktrinal keislaman (alhaqīqah al-shar'iyyah), setelah itu berdasar pengertian tradisi, baru kemudian pengertian kebahasaan. ${ }^{57}$

Berdasarkan penjelasan di atas, takwil bagi Ibn 'Arabi tidak boleh menyangkal makna zahir teks, sehingga penyingkapan makna esoterik dengan sendirinya tidak akan menegasikan perintah-perintah dan larangan-larangan syariat. Dalam konteks takwil Ibn 'Arabī Naṣr Hāamid Abū Zayd menegaskan bahwa loyalitas Ibn 'Arabī terhadap makna lahir teks tidak hanya dalam tingkatan ayat-ayat hukum dan ibadah saja, namun juga dalam tingkatan ayat-ayat akidah. ${ }^{58}$ Bahkan loyalitas Ibn 'Arabì terhadap makna lahir, dalam banyak kasus, telah mendorong beberapa ulama sezamannya mengkatategorikannya sebagai pengikut mazhab Ibn Hazm alZāhirī. ${ }^{59}$ Begitu pentingnya makna lahir karena merupakan pondasi penting yang menjadi landasan makna batin. Seseorang tak akan mampu menangkap makna batin, kecuali melalui konstruksi lahir, yang membingkainya dalam ruang-lingkup bahasa yang dapat dipahami manusia secara umum.

Dalam pandangan Ibn 'Arabi, sebagaimana sufi lain, bahasa profan manusia pada tataran semantik konvensionalnya (al-bu'd al-dala', ili al- 'urfi) adalah gema bagi bahasa Ilahi, dan merupakan salah satu manifestasinya. Dimensi semantis bahasa manusia ini mewakili tingkatan makna lahir, namun pada saat yang sama mengisyaratkan makna ilahiyah yang tersembunyi. Tak mengherankan jika para sufi bersikukuh menegaskan

${ }^{56}$ Ibn 'Arabì, al-Futūhàt al-Makkiyyah, Jilid IV, h. 106.

57 Quṭb al-Raysūnī, al-Nașs al-Qur'ānī min Tahāfut al-Qirā'ah ilā Ufuq al-Tadabbur (Rabat: Wizārāt al-Awqāf wa al-Shu'ūn al-Islāmiyyah, 2010), h. 65.

${ }^{58}$ Nașr Hāmid Abū Zayd, Falsafat al-Ta'wil,h. 26.

59 Mahmūd Ghurāb, al-Fiqh 'ind al-Shaykh al-Akbar Muhyi al-Dīn Ibn al-'Arabi (Damaskus: Maktabat Naḍar, 1993), h. 7-9. 
penting-nya dimensi lahir untuk bisa menembus kepada tingkat makna batin. ${ }^{60}$ Karena bagaimanapun, dimensi lahir merupakan tanda (al-rumz), yang tanpanya mustahil seseorang sampai pada petanda (al-marmüz). Dengan demikian, penolakan sementara ahli fiqh terhadap pena'wilan kaum sufi muncul karena miskonsepsi mereka terhadap metodologi interpretasi kaum sufi, sehingga mereka menuduh kaum sufi menanggalkan makna-makna zahir dan menyamakan mereka dengan kaum Bātiniyyah.

\section{Konteks Psikis-Spiritual sebagai Basis Pemaknaan Batin}

Konstruksi tekstual adalah basis utama bagi 'objektivasi' penafsiran, namun makna tidak sepenuhnya terpenjara dalam batasan teks. Dalam pandangan kaum sufi, Alquran adalah representasi kalam Allah yang membentang sepanjang ketidakterhinggaan (kalām qadìm). Seperti halnya kalimat kosmik Allah tidak terbatas, kalimatAlquran, meskipun komposisi harfiahnya terbatas, namun mengisyaratkan multiplisitas makna wujüdiyyah yang tak terbatas. ${ }^{61}$ Namun demikian, hanya pribadi manusia yang melakukan penycian diri secara terus-menerus, yang akan mampu menyingkap rahasia-rahasia gaib dari dalam teks Alquran. ${ }^{62}$ Oleh karenanya, makna batin merupakan capaian mistis yang terkuak bagi seorang sufi sesuai tingkat spiritualnya.

Ketika melakukan penafsiran, pengalaman intuitif yang dialami seorang sufi memaninkan peran yang sangat signifikan dalam proses pemaknaan.Pengalaman intuitif ini merupakan kondisi psiko-spiritual yang dialami oleh seorang sufi dalam hatinya, sebagai buah dari prosesperjuangan melawan nafsu dan ego rendah. Spektrum makna Alquran yang berkorespondensi dengan realitas multi-dimensi ditangkap oleh hati seorang sufi berdasarkan konteks psikis-spiritual tersebut. Perlu digarisbawahi bahwa dalam pemaknaan isyari, konteks tidak hanya berarti fenomena sosio-kultural yang mengitari proses penafsiran teks, namun lebih terasosiasikan kepada pengalaman spiritual kaum sufi ketika membaca teks suci.Berkaitan dengan hal ini, Ibn 'Arabi, sebagaimana dikutip oleh Amīr 'Abbās, menyatakan bahwa makna berpusat dalam hati, dan kemudian tersingkap bagi pembaca sedikit demi sedikit, sesuai dengan tingkat perjuangan spiritualnya. Namun bagaimana pun, tersingkapnya makna tersebut terealisasi melalui pelantara teks. ${ }^{63}$ Oleh karena itu, hati ( $\left.q a l b\right)$ bagi kaum sufi adalah kata kunci paling berharga, karena merupakan media pencerap kualitas-kualitas hakiki dalam bentangan realitas semesta. ${ }^{64}$ Kejernihan hati seorang hamba, yang ditempa melalui perjuangan melawan ego rendah, dapat memantulkan rahasia-rahasia Ilāhi di sebalik teks suci Alquran.

\footnotetext{
${ }^{60}$ Nasr Ḥāmid Abū Zayd, “Al-Lughah, al-Wujūd, al-Qur'ān: Dirāsah fĩ al-Fikr al-Ṣūfí,” al-KarmalRāmallah, No. 62 (2000): h. 159.

${ }^{61}$ Nasr Hāmid Abū Zayd, “ al-Lughah, al-Wujūd, al-Qur'ān: Dirāsah fî al-Fikr al-Șūfí,” h. 159

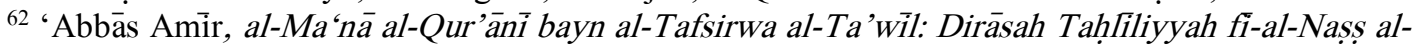
Qur'ānī(Beirut: Mu'assasah al-Intishār al-'Arabi, 2008), h. 121.

63 'Abbās Amī, al-Ma'nā al-Qur'ānì bayn al-Tafsirwa al-Ta'wìl, h. 62.

${ }^{64}$ Kabir Helminski, The Knowing Heart: A Sufi Path of Transformation (Boston \& London: Shambhala Publications, 2000), h. 71-72.
} 
Dalam al-Futūhăt-nyalbn 'Arabi secara lebih jelas menjabarkan bagaimana kaum sufi menyingkap rahasia-rahasiaAlquranmelalui hati. Beliau menjelaskan,

Pembicaraan kaum sufi dalam menjelaskan kitab agung Alquran ... adalah ungkapan-ungkapan simbolis (ishärât), meskipun pada saat yang sama juga merupakan penjelasan faktual dan bentuk penafsiran terhadap makna-makna-nya yang bernilai. Semua isharat itu tersingkap dalam hati-hati mereka, dengan tetap mengakui makna umumnya dalam bentuk kitab yang diturunkan, seperti yang dipahami oleh kalangan ahli lahir (ahl al-lisān), yang dengan bahasa mereka Alquran turun. Dengan demikian, Allah menjadikan cakupan makna Alquran menjangkau (pemahaman) dua dimensi, seperti difirmankan Allah, "Kami akan memperlihatkan kepada mereka tanda-tanda (kebesaran) Kami di segenap penjuru dan pada diri mereka sendiri," (Q.S. Fușsilat [41]: 53). Yakni, tanda-tanda yang diturunkan di alam semseta dan dalam diri-dri mereka. Maka demikian, setiap ayat yang diturunkan memiliki dua dimensi; satu dimensi mereka saksikan di dalam diri mereka, dan dimensi lain mereka saksikan di luar diri mereka ${ }^{65}$

Dari penjabaran ibn 'Arabī ini, dapat dipahami bahwa makna batin hakikatnya adalah makna-makna yang secara inherent terkandung di dalam Alquran dan tersingkap bagi orang-orang pilihan. Pemahaman makna ini bukan merupakan pemahaman asing, karena pada dasarnya berkesesuaian dengan makna tekstual dan tradisi kenabian. Dalam hal ini, secara lebih khusus Rizwan Zamir dalam artikel ilmiahnya menegaskan, tulisan-tulisan Ibn 'Arabī, termasuk berbagai penafsiran-nya terhadap Alquran, merupakan sintesis dari berbagai komponen pemaknaan, meliputi analisis literal, tradisi tranmisional, demonstrasi rasional, dan penyingkapan mistis-spritual. ${ }^{66}$ Makna teks tidak dikonstruksikan hanya oleh wawasan seorang sufi, karena bagaimanapun, teks bukanlah objek mati yang bisa digusur kemana pun oleh unsur subjektivitasnya.

Ditinjau dari perspektif psikologi, Fontana mengafismasi secara positif implikasi relasional antara kondisi psikis seseorang dengan ragam aktifitas dan tindakan-nya. ${ }^{67}$ Dengan kata lain, kondisi jiwa seseorang mempengaruhi cara dia berprilaku, termasuk bagaimana ia menginterpretasikan fenomena. Sementara melalui perspektif psikologi sufistik secara khusus, konteks psikis-spiritual seorang sufi dapat membukakan horizon baru yang berorientasikan nilai-nilai moral-spiritual di balik rangka tekstual. Hal ini karena seperti diungkapkan Frager, jiwa merupakan entitas immateri yang abadi dan tak terbatas, sebagai representasi rụh ilähi. Melalui media hati yang suci dan bersih setelah serangkaian proses olah-batin, jiwa mampu mengungkap realitas-realitas bătiniyyah yang tersembunyi di balik kompleksitas dunia fisik-material. ${ }^{68}$ Demikian dalamnya pengalaman spiritual seorang sufi, sehingga ketika membaca teks Alquran, ia

\footnotetext{
${ }^{65} \mathrm{Ibn}$ 'Arabī, al-Futūhāàt al-Makkiyyah, Jilid II, h. 20.

${ }^{66}$ Syed Rizwan Zamir, "Tafsir al-Qur'an bi'l Qur'an: The Hermeneutics of Imitation and Adab in Ibn 'Arabī's Interpretation of the Qur'ân," h. 7.

${ }^{67}$ David Fontana, Psychology, Religion, and Spirituality (Malden: BPS Blackwell, 2003), h. 23-24.

${ }^{68}$ Robert Frager, Hati, Diri, dan Jiwa: Psikologi Sufi untuk Transformasi Jiwa, terj. Hasmiyah Rauf (Jakarta: Serambi, 2005), h. 55-56.
} 
dapat menangkap makna batin di samping makna zahir teks, sesuai dengan tingkatan maqām dan hāl-nya.

Kesimpulannya, konteks psiko-spiritual yang dialami seorang sufi berkontribusi besar bagi penyingkapan makna esoterik Alquran yang secara ontologis berkorespondensi dengan hakikat realitas. Ibn 'Arabi, sebagaimana sufi lain, menisbatkan pemahaman takwil sufistik ini khusus kepada orang-orang yang berjiwa suci, yang terlebih dahulu melakukan prosesi perjuangan spiritual (al-mujāhadah) dan penyucian jiwa (tașfiyyat al-nafs) tiada henti. Hal ini karena baginya, pemahaman dan penyingkapan makna spiritual dalam Alquran hanya dapat memantul secara jernih pada media hati yang juga bersih.Namun segera perlu diingatkan bahwa makna batin bukan merupakan makna yang mendekonstruksi tatanan teks suci, melainkan makna intrinsik yang jusrtu mengungkapkan nuansa moral-spiritual teks Alquran.

\section{Makna Isyari: Dialektika antara Teks dan Konteks}

Teks bagi pihak mutakallim (pembicara/ penulis) memiliki satu makna sesuai kehendaknya (al-dalālah al-ḥaqiqiyyah), namun pihak mukhätab (pendengar/ pembaca) tidak dapat memastikan maksud itu, sehingga makna teks itu baginya bersifat relatif (al-dalālah al-nisbiyyah). Pemahaman pihak mukhätab terhadap teks akan banyak dipengaruhi oleh konteks yang berbeda, sehingga pada gilirannya mengakibatkan ragam penafsiran. ${ }^{69}$ Dalam konteks interpretasi Alquran, makna hakiki adalah hak prerogatif Allah sebagai Pembicara. Setiap penafsir dituntut untuk mengerahkan segenap kemampuannya untuk menyingkap makna Alquran, namun tak satu pun berhak mengklaim bahwa penafsirannya adalah makna yang dikehendaki-Nya. Makna Alquran dengan demikian tidak dapat ditangkap hanya melalui petunjuk tekstual saja, karena selainnya, terdapat banyak media yang berfungsi untuk mengungkapnya, meliputi berbagai kejadian, kondisi, dan situasi mental yang terlibat ketika proses pemaknaan berlangsung. ${ }^{70}$

Dari perspektif takwil isyari, makna tidak terbatas pada apa yang tampak pada lapisan eksternal teks yang didapat melalui analisis bahasa dan informasi-informasi profetik, namun juga mencakup singkapan-singkapan spiritual yang berada di baliknya. Teks bukan merupakan suatu fenomena komunikasi yang memiliki akhir, namun teks dipahami sebagai mesin yang secara berkelanjutan menyuguhkan makna-makna baru, sesuai dengan situasi dan momen pembaca. ${ }^{71}$ Teks dengan demikian merupakan simbol yang menyiratkan pusaka makna-makna terpendam di kedalamannya. Hal inilah yang menyebabkan makna-makna bereda, yang berkembang tanpa jeda, selaras dengan

${ }^{69}$ Nasarudin Umar, Deradikalisasi Pemahaman al-Qur'ān dan al-Hadis (Jakarta: PT. Elex Media Komputindo, 2014), h. 54.

${ }^{70}$ Tamām Ḥassān, “Zilāl al-Ma‘ānī fĩ al-Qur'ān al-Karìm,” Journal of Qur'anic Studies, Vol. 7, No. 1 (2005): h. 136. 68-69.

${ }^{71}$ Ian Almond, Sufism and Deconstruction: A Comparative Study of Derrida and Ibn 'Arabī, h. 
perbedaan tingkatan cakrawala pembaca. Terkait dengan ragam makna yang diakibatkan oleh perbedaan kapasitas pembaca, Ibn 'Arabī menuturkan,

Bisa jadi suatu ayat Alquran sama bunyinya dalam pendengaran (para audien), namun seseorang memahami darinya satu hal, sedangkan seorang yang lain tidak menangkap hal itu namun malah memahami hal lain, sementara orang lain mampu memahami dari-nya lebih banyak makna. Dengan demikian, setiap orang yang berfikir akan berargumentasi dengan pemahaman-nya yang berbeda terhadap Alquran, karena perbedaan potensialitas pemahaman (isti ${ }^{6} d \bar{a} d$ al-afhām).$^{72}$

Namun demikian, kaum sufi sendiri menyadari bahwa penyingkapanpenyingkapan spiritual yang mereka dapatkan adalah pengalaman subjektif-personal, sehingga memiliki kemungkinan penyimpangan. Oleh karena itu, dalam konteks interpretasi isyari, komposisi eksoterik Alquran, yang dikonstruksikan oleh pendekatan kebahasaan dan tradisi kenabian, merupakan barometer inti yang digunakan untuk mengukur validitas pemaknaan spiritual. Maka demikian, meskipun orientasi tafsir isyari merupakan mistis-spiritual, namun hal ini tidak berarti penegasian makna tekstual Alquran. Penyingkapan spiritual kemudian harus didialogkan terlebih dahulu dengan konstruksi tekstualnya. Karena bagaimanapun, petunjuk tekstual beserta komunitas makna yang dibangun di atasnya merupakan pijakan inti bagi usaha interpretasi secara umum, yang akan mengantisipasipotensi kesewenang-kenangan dan relativisme penafsiran. ${ }^{73}$

Ibn "Arabī memandang bahwa Alquran sebagai "ekspresi bahasa Tuhan" (His linguistic self-expression) ${ }^{74}$ yang setiap hurufnya berkoresponden dengan keadaan praeksistensinya di al-lawh al-mahfü. Pelabrakan terhadap susuan literal Alquran sama saja dengan pembangkangan terhadap otoritas Tuhan itu sendiri. Makna batin pada dasarnya tidak mendekonstruksi tatanan tekstual Alquran karena pada dasarnya merupakan makna 'lanjutan' dari makna zahir, sehingga lebih tepat dikategorikan sebagai makna pelengkap. Ibn 'Arabì dalam hal ini menjelaskan, "Orang yang menaati zahir (Alquran), akan tampak baginya dalam hal lahir ini pengetahuan yang tak pernah terbayang dalam benak siapa pun sebelumnya, (yakni) bahwa ilmu yang diketahui oleh ahli kashf (hakikatnya) terkandung oleh sisi zahir tersebut." ${ }^{55}$ Maka dari itu,Abū Zayd berargumen, penafsiran sufistik tidak termasuk kategori ta'wïlbatīini, karena pada dasarnya merupakan isharat-isharat spiritual yang termuat dalam teks dari segi signifikansi, bukan sebagai makna utama. ${ }^{76}$ Signifikansi merupakan "makna bayangan" yang menambah spekturm kandungan teks, bukan malah menghancurkan tatanannya.

Berdasarkan penjelasan di atas, signifikansi makna yang didapat seorang sufi dapat dikatakan merupakan hasil 'dialektika' antara makna tekstual dengan pencerapan

${ }^{72} \mathrm{Ibn}$ 'Arabi, al-Futūhàt al-Makkiyyah, Jilid II, h. 32.

${ }^{73}$ Khaled M. Abou el-Fadl, And God Knows the Soldiers (New York: University Press of America, 2001), h. 94-95.

${ }^{74}$ William C. Chittick, Ibn 'Arabī: Heir to the Prophets, h. 17.

${ }^{75}$ Maḥmūd Ghurāb, al-Fiqh 'ind al-Shaykh al-Akbar Muhyyi al-Dīn Ibn al-'Arabi, h. 47.

${ }^{76}$ Nasr Hāmid Abū Zayd, Mafhūm al-Nașș: Dirāsah fì 'Ulūm al-Qur'ān,h. 234 
batin spiritual. Makna secara inherent bersifat kontekstual dalam artian tidak statis, karena pergeserannya mengikuti kondisi psikis-spiritual seorang sufi. Dalam proses mental ini, kaum sufi tidak menegasikan makna pertama yang segera dipahami dari tatanan tekstual (al-mutabādar). Hanya saja, penyempitan makna sebatas pada tingkatan eksternal Alquran merupakan tindakan represif, yang justru mencerabut intimasi komunikasi teks suci dengan hati-hati yang merindukan kehadiran Allah sang Pembicara. Dalam kaitan ini, Ibn 'Arabi berwasiat bahwa kita semua sepat utnya membaca Alquran dengan penuh perenungan, karena sebagaimana diturunkan kepada kalbu Muhammad, makna-makna Alquran juga diturnkan kepada setiap hati pembaca ketika membacanya, sehingga Alquran seakan turun secara terus menerus. ${ }^{77}$ Ini artinya bahwa horizon 'mental' setiap pembaca memungkinkan pembacaan yang berbeda terhadap teks suci yang sama.

Proses takwil isyari secara umum dan takwil Ibn 'Arabi secara khusus, bisa dibaca melaluipendekatan hermeneutis Abū Zayd yang menyatakan bahwa pencapaian signifikansi makna (al-maghzā), yang pada dasarnya merupakan pemaknaan lanjutan atas makna teks (dalālat al-naș̣). Mekanisme takwil mengharuskan seorang mufasir menguasai berbagai disiplin ilmu yang berkaitan dengan aspek kebahasaan dan ilmulimu Alquran yang banyak bertumpu pada aspek periwayatan (al-ma'thür). Aspek kebahasaan dan 'ulūm al-qur'ān memungkinkannya memahami makna 'objektif', yang dalam tradisi interpretasi Alquran diistilahkan dengan makna tafsir. Takwil yang tidak berpegang kepada tafsir adalah jenis takwil yang tidak diperbolehkan, karena memahami Alquran tidak boleh hanya berdasar pada spekulasi murni, dengan cara menundukan teks kepada ego subjektif dan ideologi penafsir. ${ }^{78}$

Untuk sampai pada makna signifikansi, takwil harus terlebih dahulu bersandar kepada makna original-tekstual, karena bagaimanapun, teks Alquran memiliki makna historis (al-dalālah al-tārikhiyyah), yakni konteks original di mana teks dipahami oleh audiens pertama, yang tanpanya seseorang tidak bisa langusng melompat untuk mengkontekstualisasikan teks tersebut. ${ }^{79}$ Bagaimanapun, konteksualisasi akan membutuhkan makna original ini sebagai tahapan awal yang penting dalam upaya menangkap signifikansi makna. Bagi Nașr Hāamid, pendapat yang mengatakan bahwa takwil merupakan proses rasional-subjekstif yang bertujuan untuk menundukan teks kepada horizon pemikiran mufasir semata, merupakan pandangan yang melupakan otoritas teks beserta khazanah penafsirannya dalam mempengaruhi pemikiran mufasir tersebut. Hubungan antara pembaca dengan teks, dengan demikian, bukan merupakan hubungan penundukan (ikhḍa') dari pihak pembaca dan ketundukan (khuḍu') dari

${ }^{77}$ Kautsar Azhari Noer, "Hermeneutika Sufi: Sebuah Kajian atas Pandangan Ibn Arabi tentang Takwil al-Qur'an," h. 320.

78 Naṣr Hāmid Abū Zayd, Mafhūm al-Nașs: Dirāsah fī 'Ulūm al-Qur'ān (Kairo: Dār al-Tanwīr, 1993), h. 232-241.

${ }^{79}$ Naṣr Ḥāmid Abū Zayd, Naqd al-Khițāb al-Dīnī (Kairo: Sinnā li-al-Nashr, 1994), h. 118-119. 
pihak teks. Namun hubungan di antara keduanya merupakan hubungan dialekstis, di mana keduanya secara mutual saling mempengaruhi. ${ }^{80}$

Dalam konteks takwil Ibn 'Arabī, sebagaimana takwil isyari secara umum, dialektika antara tatanan teks dengan cakrawala jiwa seorang sufi ketika membaca teks suci memproduksi signifikansi makna yang mengacu pada hakikat-hakikat spiritual. Namun proses kontekstualisasi isyari ini sama sekali tidak berimplikasi terhadap dekonstruksi tatanan tekstual Alquran, karena pada dasarnya makna spiritual merupakan makna lanjutan, yang tidak merusak makna original. Hubungan antara teks dengan konteks batin merupakan hubungan dialektis yang saling memperkaya, bukan malah saling menegasikan.

\section{Penutup}

Berdasarkan hasil penelitian di atas, penulis menyimpulkan bahwaepistemologi takwilsufistikbesifat kompleks, sehingga tidak bisadilihat dari satu perspektif saja. Membaca pemaknaan isyari hanya melalui satu sudut pandang akan memberikan gambaran yang tak utuh, sehingga tak jarang mengakibatkan kesalahpahaman terhadapnya.Epistemlogi takwil yang digagas oleh Ibn 'Arabi tidak bisa dilepaskan dari kosmologi sufitik yang memandang multiplisitas alam. Teks Alquran bagi Ibn 'Arabi adalah cerminan dari realitas multi-dimensi ini, sehingga pada dirinya sendiri memiliki potensi multiplisitas makna. Makna lahir dengan demikian bukan satusatunya makna Alquran, sebagaimana alam empiris bukan satu-satunya alam ciptaan. Tapi tidak semua orang bisa mengakses dimensi esoteris dari konstruski tekstual Alquran. Hanya kondisi jiwa yang suci, menurut Ibn 'Arabi, yang bisa menyingkapnya. Maka dari itu, konteks psikis-spiritual, yang tak lain adalah tingkatan mistik seorang sufi, berpengaruh sangat besar dalam menyibakkan tirai-tirai 'kelegapan' teks suci. Namun demikian, "ektase hermeuneutis" seorang sufi tidak diperkenankan untuk berlepas dari kendali eksoterisme Alquran, karena menurut Ibn 'Arabī, setiap huruf Alquran adalah representasi kalam Allah yang menuntut ketaatan dan pengagungan mutlak. Takwil dengan demikian adalah proses dialektis antara teks suci dengan konteks batinseorang sufi secara harmonis dalam menegosiasikan ragamkemungkinan makna, sebagai cerminanrealitas multi-dimensi.

${ }^{80}$ Nașr Ḥāmid Abū Zayd, Falsafat al-Ta’wīllh. 5-6. 


\section{DAFTAR PUSTAKA}

Abū Bakr, Omaima. "The Symbolic Function of Methapor in Medieval Sufi Poetry: The Case of Shustari," Alif: Journal of Comparative Poetics, No. 12, Metaphor and Allegory in the Middle Ages (1992): p. 40-57.

Abū Zayd, Naṣr Hāamid.Falsafat al-Ta'wìl: Dirāsah fì Ta'wīl al-Qur'ān 'Ind Muhyi alDìn bin 'Arabī. Beirut: Dār al-Wiḥdah, 1983.

-------.Mafhūm al-Nașs: Dirāsah fì 'Ulùm al-Qur'ān.Kairo: Dār al-Tanwìr, 1993. Naqd al-Khitāàb al-DīnīKairo: Sīnā li-al-Nashr, 1994.

-------. “Al-Lughah, al-Wujūd, al-Qur'ān: Dirāsah fî al-Fikr al-Ṣūfî,” al-KarmalRāmallah, No. 62 (2000): pp. 156-186.

Abou el-Fadl, Khaled M. And God Knows the Soldiers.New York: University Press of America, 2001.

Almond, Ian. "The Meaning of Infinity in Sufi and Deconstructive Hermeneutics: When Is an Empty Text an Infinite One?,"Journal of the American Academy of Religion, Vol. 72, No. 1 (Mar., 2004): p. 97-117.

-Sufism and Deconstruction: a Comparative Study fo Derrida and Ibn 'Arabi. London: Routledge, 2004.

Amìr, 'Abbās. Al-Ma'nā al-Qur'ānì bayn al-Tafsirwa al-Ta'wīl: Dirāsah Taḥlìliyyah fīal-Nașs al-Qur'ānī.Beirut: Mu' assasah al-Intishār al-'Arabì, 2008.

Campanini, Massimo. The Qur'ān: The Basics, trans. Oliver Leaman. London and New York, Routledge, 2007.

Chittick, Wiliam C. "Time, Space, and the Objectivity of Ethical Norms: The Teachings of Ibn al-'Arabī," Islamic Studies, Vol. 39, No. 4, Special Issue: Islam and Science (Winter 2000): p. 581-596.

-------. The Sufi Path of Knowledge: Hermeneutika al-Qur'ān Ibnu al-'Arabi, terj. Ahmad Nidjam. Yogyakarta: Qalam, 2001.

-------. Dunia Imajinal Ibnu 'Arabi: Kreativitas Imajinasi dan Persoalan Diversitas Agama, terj. Ahmad Syahid. Surabaya: Risalah Gusti, 2001.

------. Ibn 'Arabi: Heir to the Prophets. Oxford: Oneworld, 2005.

Chodkiewicz, Michel. An Ocean Without Shore: Ibn Arabi, The Book, and the Law.New York: State University of New York Press, 1993.

Corbin, Henry.Creative Imagination in The Sufism of Ibn 'Arabi. New York: Routledge, 2008.

Farghali 'Ali al-Qarni, 'Abd al-Hafị. Muhyi al-Dīn Ibn 'Arabìi: Sultān al-'Arifinn.Kairo: Hay’ah al-Mișriyyah al-'Ämmah li-Al-Kitāb, 1986.

Fontana, David.Psychology, Religion, and Spirituality.Malden: BPS Blackwell, 2003.

Frager, Robert.Hati, Diri, dan Jiwa: Psikologi Sufi untuk Transformasi Jiwa, terj. Hasmiyah Rauf. Jakarta: Serambi, 2005.

Al-GhazāTi, Abū Ḥāmid.Faụāị al-Batiniyyah.Beirut: Maktabat al-'Așriyyah, 2011.

Ghurāb, Mahmūid.Al-Fiqh 'ind al-Shaykh al-Akbar Muhyi al-Dìn Ibn al-'Arabi. Damaskus: Maktabat Nadiar, 1993.

Goldziher,Ignaz.Mazhab Tafsir: dari Aliran Klasik Hingga Modern, terj. M. Alaika Salamullah, dkk. Yogyakarta: eLSAQ Press, 2006. 
Hassān, Tamām. “Zilāl al-Ma'ānì fĩ al-Qur'ān al-Karìm,” Journal of Qur'anic Studies, Vol. 7, No. 1 (2005): p. 200-172.

Helminski, Kabir.The Knowing Heart: A Sufi Path of Transformation. Boston \&London: Shambhala Publications, 2000.

Ibn 'Arabī, Muhȳìi al-Dīn.Al-Futūhāat al-Makkiyyah, IX Jilid. Beirut: Dār Ihỵā' alTurāth al-'Arabì, 2010.

Al-Jābiri,'Abid.Takwīn al-'Aql al-'Arabī.Beirut: Markaz Dirāsāt al-Wahdah al'Arabiyya, 2002.

Al-Jiliand, Muhammad al-Sayyid.Al-ImāmIbn Taymiyyah wa Mauqifuhu min Qadiyyat al-Ta'wil.Jeddah: Maktabah 'Ukaz, 1983.

Kamali, Mohammad Hashim. The Principles of Islamic Jurisprudence.Geneva: Islamic Texts Society, 1989.

Khurshīd, Ibrahīm Zakkì.Müjaz Dā'irat al-Ma'ārif al-Islāmiyyah. Kairo: Markaz alShāriqah, 1998.

Al-Muhạāibīi, Al-Ḥārith bin Asad.Al-'Aql wa Fahm al-Qur'ān.Beirut: Dār al-Fikr, 1971.

Musharaf, Maryam. "a Study on the Sufi Interpretation of Qur' an and the Theory of Hermeneutic," al-Bayan Journal, Vol. 11, No. 1 (June 2013): p. 33-47.

Nicholson, Reynold A. Studies in Islamic Mysticism. London: Curzon Press, 2005.

Noer, Kautsar Azhari.Tasawuf Perenial: Kearifan Kritis Kaum Sufi. Jakarta: Serambi, 2003.

-------. "Hermeneutika Sufi: Sebuah Kajian atas Pandangan Ibn Arabi tentang Takwil al-Qur'an," Kanz Philosophia, Vol. 2, No. 2 (Desember 2012): p. 309327.

Rahman, Fazlur.Islam and Modernity: Transformation of an Intellectual Tradition.Chicago: The University of Chicago Press, 2009.

Al-Raysūnī, Quṭb.Al-Nașs al-Qur'ānī min Tahāfut al-Qirā'ah ilā Ufuq alTadabbur.Rabat: Wizārāt al-Awqāf wa al-Shu'ūn al-Islāmiyyah, 2010.

Renard, Jhon.Historical Dictionary of Sufism.Maryland, Toronto, \& Oxford: The Scarecrow Press, 2005.

Rizvi, Sajjad H. "The Existential Breath of al-Rahmān and the Munificent Grace of alrahīm: The Tafsīr Sūrat al-Fātiḥah of Jāmi' and the School of Ibn 'Arabī,"Journal of Qur'anic Studies, Vol. 8, No. 1 (2006): p. 58-87.

Al-Sha'rānì, al-Imām.Al-Yawāqìit wa-al-Jawāhīr fi-Bayān 'Aqā'id al-Akābir. Beirut: Dār Ihỵā' al-Turāth al-'Arabìi, t.t.

Salahudin, Asep. "Konstruksi Epistemologi Tasawuf," dalam dalam Tarekat Qādiriyyah Naqshabandiyyah Pondok Pesantren Suryalaya Membangun Peradaban Dunia, ed. Ajid Tohir. Suryalaya: Mudawaha warohmah Press, 2011.

Sands, Kristin Zahra.Sufi Commentaries on the Qur'ān in Classical Islam. New York: Routledge, 2006.

Schimmel, Annemarie.Mystical Dimensions of Islam.North Calorina: The University of North Carolina Press, 1975.

Shihab, M. Quraish. Kaidah Tafsir.Ciputat: Lentera Hati, 2013.

Stodart, William.Outline of Sufisme: The Essentials of Islamic Spirituality. Indiana: World Wisdom, 2012.

Al-Ṣubhānīi, Ja'far.Al-Madkhal ilā al-'Ilm wa al-Falsafah wa al-Ilāhiyyāt: Nazariyyat al-Ma'rifah.Beirut: al-Dār al-Islāmiyyah, 1990. 
Umar, Nasarudin.Deradikalisasi Pemahaman al-Qur'ān dan al-Hadis.Jakarta: PT. Elex Media Komputindo, 2014.

Al-Wāṣifî, Abū 'Abd al-Raḥmān.Mawāzīn al-Ṣüfiyyah.Alexandria: Dār al-Īmān, 2006.

Zamir, Syed Rizwan. "Tafsìr al-Qur'ān bi'l Qur'ān": The Hermeneutics of Imitation and "Adab" in Ibn 'Arabī's Interpretation of the Qur'ān," Islamic Studies, Vol. 50, No. 1 (Spring 2011): p. 5-23. 